\title{
Knowledge, approach and status of early marriage in Bangladesh
}

\author{
A.K.M. Fahmidul Haque ${ }^{1,2}$, Md. Niajur Rahman ${ }^{1,3, ~ *, ~ A r i f-u z-Z a m a n ~ K h a n ~}{ }^{1}$, \\ Israt Jahan Mukti ${ }^{2}$, Begum Lutfunnahar ${ }^{4}$ \\ ${ }^{1}$ Atish Dipankar University of Science and Technology, ARA Estate, 69/E Kazi Biruttam Nuruzzaman Road, Dhaka, Bangladesh \\ ${ }^{2}$ Institute of Appropriate Technology (IAT), Bangladesh University of Engineering and Technology, Polashi, Dhaka, Bangladesh \\ ${ }^{3}$ Directorate General of Family Planning, Ministry of Health and Family Welfare, 6-Kawran Bazar, Dhaka, Bangladesh \\ ${ }^{4}$ Mymensingh Medical College, Chorpara, Mymensingh, Bangladesh
}

\section{Email address:}

fahmidulhaque@yahoo.com (A. K. M. Fahmidul Haque), niajur.fp@gmail.com (Md. N. Rahman), piashrubel21@yahoo.com (Arif-Uz-Zaman Khan), mukti_bge@yahoo.com (I. J. Mukti), begum_lutfunnahar@yahoo.com (B. Lutfunnahar)

\section{To cite this article:}

A.K.M. Fahmidul Haque, Md. Niajur Rahman, Arif-uz-Zaman Khan, Israt Jahan Mukti, Begum Lutfunnahar. Knowledge, Approach and Status of Early Marriage in Bangladesh. Science Journal of Public Health. Vol. 2, No. 3, 2014, pp. 165-168.

doi: $10.11648 /$ j.sjph.20140203.14

\begin{abstract}
Early marriage is a key indicator to assess the development of a nation. Early marriage is specifically associated with some unavoidable predicament like social and physical outcomes, mood disorders, depression, anxiety, obsessive and makes dismay. Even the possibilities of iron and calcium deficiency in pregnancy under the age of 18 will be increased which leads to osteoporosis and anaemia. It also enhances the risk of Cervical Cancer as well. A descriptive type of cross sectional study was conducted to assess the knowledge, approach and status of early marriage in Bangladesh where 300 eligible couples of the reproductive age were taken as sample. Data was collected through structured questionnaire by face to face interview and analyzed by SPSS version 17.0 including descriptive statistic using mean, standard deviation, percentage, Chi-square test to describe the association. The respondents got married at the age of $16.19 \pm 3.522$ (Female) $(\mathrm{Mean} \pm \mathrm{SD}$ ) years and $22.22 \pm 10.532$ (Male) years where the frequency of early marriage was $65 \%$ in Bangladesh. Only $22 \%$ respondents had no standard education and $63.3 \%$ female respondents were housewife which showed that the rate of literacy and working women is increasing in Bangladesh even a significant association exists between age of early marriage and occupation of the respondents ( $\mathrm{x}^{2} 10.433$ with $\mathrm{P}$ value 0.034$) .81 .3 \%$ respondents were nuclear family and had a significant relation between type of the family and age of the early marriage $\left(x^{2} 4.136\right.$ with $\mathrm{P}$ value 0.042$)$. Average monthly household income was $12,226 \pm 5,787.366$ taka where $10.3 \%$ had $<5000$ taka and $4 \%$ had income $>20000$ taka. $55.33 \%$ had no marriage registration and $15.3 \%$ had no child birth registration of their child. All the respondents agreed to stop early marriage and showed positive attitude where $99 \%$ thought for female $<18$ years will not suitable for marriage. These study results specifically showed the necessity of Bangladesh to give more attention on this issue to graduate from Least Developed Country (LDC) list.
\end{abstract}

Keywords: Childhood Marriage, Child Marriage, Adolescent Marriage, Forced Marriage, Bangladesh

\section{Introduction}

The 1948 Universal Declaration of Human Rights recognizes the right to "free and full" consent to marriage. It acknowledges that this standard is not met when a person is not mature enough to make an informed decision [1]. The Universal Declaration of Human Rights and the Convention on the Elimination of All Forms of Discrimination Against Women (CEDAW) specifically stipulate that marriage should require free and full consent. CEDAW, which is ratified by 186 countries, explicitly states that "the betrothal and marriage of a child shall have no legal effect" (Article 16.2) [2]. A minimum age of marriage of 18 for both girls and boys is recommended by the committees of both CEDAW and Convention on the Rights of the Child (CRC) [3] whereas the Sharia law says boys at the age of 15 and girls at the age of 9 become sexually matures [4]. In the context of Bangladesh, if 
anyone get married before the age of 18 for female or before the age of 21 for male is called early marriage. The frequency of early marriage is quite high especially in South Asia and Sub-Saharan Africa. Current status of child marriage indicates 14.2 million girls annually or 39,000 daily will marry too young [5]. In Bangladesh the majority took place for the early marriage who are illiterate, poor, having large family size, not aware about the actual age of marriage etc. and $81 \%$ women were married before the age of 18 [6] which is much higher than the regional average for South Asia (48\%) [1]. Even the women who are 20 to 24 years old will marry or enter into union annually before age 18 will become 27.9 million in South Asia by 2030 [7]. In 2010, 4,806,000 Bangladeshi women aged 20-24 were married or entered into union before age 18. If present trends continue then $4,597,000$ of the young girls who was born between 2005 to 2010 will be married or entered into union before age 18 by 2030 [7]. Government and different nongovernment organizations are working on this issue and the median age of first marriage is gradually increasing but this improvement has been limited primarily to girls of families with higher incomes [8, 9]. National and international communities are recognizing early marriage as a serious challenge with violation of human rights and as a barrier to key development outcomes as well.

Early marriage is associated with some unavoidable predicament like social and physical outcomes, mood disorders, depression, anxiety, obsessive and make dismay [10]. Iron and calcium deficiency is most common in pregnancy under the age of 18 which leads to osteoporosis and anaemia $[11,12]$. It also increases the risk of Cervical Cancer [13, 14]. Usually, the female partner attain lower schooling levels, lower social status in their husbands' families, less control on reproduction and suffer higher maternal mortality rate and domestic violence. Under the age of 18 years mother's infant has the risk of death at first year of life and it is $60 \%$ greater than that of an infant whose mother is older than 19 [15]. Even if the children survive, he or she will suffer from low birth weight, malnutrition and late physical and cognitive development with child brides at risk of violence, abuse and exploitation [15]. The births and newborn deaths are 50\% higher among mothers age below 20 year than woman pregnant in 20 years of age [7]. Nearly 16 million teenage girls aged 15 to 19 years old in developing countries give birth every year [7]. Again in Bangladesh, the husband is older than young wife and it is difficult to insist their husbands to use condom. Because of age difference the husband are more sexually experienced, making the girls vulnerable to HIV and other sexually transmitted infections [16]. Though marriage is a way to get social and religious acceptance but early marriage hinders the social and physical achievements.

\section{Materials and Methods}

A descriptive type of cross sectional study was conducted to assess the knowledge, approach and status of early marriage in Bangladesh. The study area was 2 districts of Bangladesh named Manikganj and Sirajganj. The target populations of the study were eligible couple of the reproductive age with the Sample size 300 where 51 were male and rests of all were female. Written informed consent witnessed by husband or legal guardian was taken and if individual showed any interest to leave out then the person was excluded immediately. Data was collected through structured questionnaire by face to face interview. After data collection, it was analyzed by SPSS version 17.0 including descriptive statistic using mean, standard deviation (SD), percentage and Chi-square test to describe the association between independent variable and dependent variable.

\section{Results and Discussion}

The average age of the respondents of this study was $34.55 \pm 6.359$ (Mean \pm SD) where the total respondents' ages were 20-45 years and highest respondents were from the age group 35-39 (34.0\%) years. Among the study population $96.7 \%$ were Muslim and only $3.3 \%$ were other religion. $83.00 \%$ of the respondents were female and rests of the $17.00 \%$ were male. The average age of the respondents got married (Female) at the age of 16.19 \pm 3.522 (Mean \pm SD) years and 22.22 \pm 10.532 (Male) years which is identical to Afghanistan [17] and Iran [18]. The frequency is still so high in South Asia; in Bangladesh 66\% [7], in Nepal 57\%, in Afghanistan 54\% and in India 50\% [6]. Very inadequate data exists on marriages of children under the age of 10, even less on those below that age [6] but a report stated that approximately $2 \%$ women of Bangladesh are married before the age of 11 [19]. About one third of the respondents $(36.33 \%)$ had primary education, $30.0 \%$ had secondary education and $14.0 \%$ only can sign their name where $42.3 \%$ guardians of the respondents had primary education, $25.3 \%$ had secondary education, $14.3 \%$ only can sign their name and $7.7 \%$ had no illiteracy at all while the literacy rate of the population aged above 15 reached to $59.82 \%$ in Bangladesh [20]. A significant relation between age of early marriage and education level of the respondents ( $\mathrm{x}^{2} 53.54$ with $\mathrm{P}$ value 0.000$)$ was found. More than half of the respondents $(63.3 \%)$ were housewife. Among the rest of all, $19.3 \%$ were in government service, $4.7 \%$ were in business, $3.7 \%$ were in non-government service and $9 \%$ were involved with agriculture. So that the percentage of working women (21\% in 2007) [21] had increased where $30.0 \%$ of the respondents' husbands were in non-government service, $23.7 \%$ were in business, $7.3 \%$ were in government service, $5 \%$ were daily labor, $10.3 \%$ were involved with agriculture and rest of the $6.7 \%$ were in foreign country as skilled or un-skilled labor. The result showed that there was a significant association between age of early marriage and occupation of the respondents $\left(\mathrm{x}^{2}\right.$ 10.433 with $\mathrm{P}$ value 0.034$)$. Most of the respondents $(81.3 \%)$ were from nuclear family and only $18.7 \%$ were 
from joint family which showed a significant relation between type of the family and age of the early marriage of the respondents $\left(\mathrm{x}^{2} 4.136\right.$ with $\mathrm{P}$ value .042 ). $45.0 \%$ respondents were lived in Semi-Concrete, $22.66 \%$ were lived in Concrete and $18.3 \%$ were lived in tin house. Average monthly household income was $12,226 \pm 5,787.366$ taka where $38.3 \%$ respondents' had between 10,001 to 15,000 taka, $10.3 \%$ had $<5000$ taka and $4 \%$ had $>20000$ taka. But the average national income in Bangladesh is 9,648 taka (Rural) and 16,475 Taka (Urban) per month [22]. So, many of the respondents had to suffer a lot to manage their daily expenditure. The study findings elicited that more than half of the respondents $(55.33 \%)$ had no marriage registration but in Bangladesh Marriage registration at kazi office is mandatory for the entire Muslims [23] and it is the most important determining factor for early marriage. Most of the respondents $(84.7 \%)$ had birth registration of their child but still15.3\% respondents' had no child birth registration but birth registration is a fundamental human right specified in CRC [3] and it is compulsory for all citizen of Bangladesh by the Births and Deaths Registration Act-2004 [24]. Birth registration of the child is another important determining factor for early marriage.

Most of the respondents $(99.0 \%)$ were first informed about the early marriage from health and family planning field worker but television, radio, newspaper, educational institute, family member etc. also helped them to gather knowledge whereas $84.7 \%$ respondents were watched television, $5.7 \%$ were listened radio and $5.33 \%$ were read newspaper regularly. Most of the respondents $(92.30 \%)$ had adequate knowledge about early marriage even $15.38 \%$ had fair knowledge and $84.61 \%$ had sufficient knowledge about the appropriate age to be pregnant. But still the frequency of teenage pregnancy is higher in Bangladesh [25] and the rate is decreasing gradually [26]. Many young people do not feel comfort to discuss about sexuality and marriage related issues with parents or other key adults [27-29] which is an important factor to disseminate the right information of early marriage. The study identified some reasons behind the early marriage which includes illiteracy, superstition, lack of awareness, domination, poverty, weak decision making power of the female members' which are comparable with Iran [18]. The respondents also agreed to stop early marriage and showed positive attitude against early marriage. Specifically they answered early marriage is destructive for family as well as for the society and should be punishable. It also hampers to take care of aged parents whereas $98.7 \%$ respondents reflected that parents play the vital role in decision making for marriage. Near about half of the respondents $(41.0 \%)$ thought that the suitable age of marriage for female is 20 years. $30 \%$ thought 18 years and $28 \%$ thought 24 years. All of them suggested that to discuss with the female members for decision making, take consent from the candidature, strengthen the local government and local administration, take a social movement against dowry, cover the marriage and birth registration all over the country and putting the actual date of birth in marriage registration. The results revealed that $26.66 \%$ of the respondents arranged early marriage for lack of security, $23.33 \%$ of the respondents arranged early marriage for free from liability and $8.33 \%$ of the respondents arranged early marriage for poverty. Boys tend to marry young girls in rural areas in Iran [18] which is also applicable for Bangladesh.

\section{Conclusion}

The study showed the present scenario of early marriage in Bangladesh where the trend is gradually decreasing day by day. But to become middle income country from least developed country (LDC) Bangladesh needs to develop in health, economic, technology, education and social sectors more frequently. Early marriage is a major hindrance to ensure the way to develop and it should be taken as a key indicator to assess the development of these sectors. The study results specifically showed the necessity to give more attention on this issue.

\section{Acknowledgements}

This study has been funded through internal support provided by the Atish Dipankar University of Science and Technology. The Authors acknowledge with gratitude to the Atish Dipankar University of Science and Technology (ADUST).

\section{References}

[1] UNICEF. Child marriage: A Harmful Traditional Practice. A Statistical Exploration 2005. New York: UNICEF

[2] The Universal Declaration of Human Rights and the Convention on the Elimination of All Forms Discrimination Against Women (CEDAW) 1979; article 16.2, http://www.un.org/womenwatch/daw/cedaw/text/econventio n.htm\#article16

[3] Convention on the Rights of the Child (CRC)-1989

[4] Rafati A, Criteria for determining maturity stage in Islam. Retrieved March 2014, from http://www.rafatinaeeni.com/Portal/Cultcure/Persian/Catego ryID/14806/CaseID/94958/71243.aspx

[5] World Health Organization, Media Centre, Child Marriages: 39,000 every day, New York, March 7, 2013, Retrieved March, 2014 from http://www.who.int/mediacentre/news/releases/2013/child_ marriage_20130307/en/

[6] UNICEF. Child marriage in South Asia: A Discussion Paper. [Online] Retrieved March, 2014 from http://www.unicef.org/rosa/earlymarriage(lastversion).doc

[7] United Nations Population Fund, Marrying Too Young: End Child Marriage, 64 (2012), Retrieved March, 2014 from http://www.unfpa.org/webdav/site/global/shared/documents/ publications/2012/MarryingTooYoung.pdf 
[8] United Nations Children's Fund. Child protection from violence, exploitation and abuse. New York: United Nations Children's Fund; 2012. Retrieved March, 2014 from http://www.unicef.org/protection/57929_58008.html

[9] Nawal M.N., Child Marriage: A Silent Health and Human Rights Issue. Rev Obstet Gynecol. 2009; 2(1):51-6.

[10] Le Strat Y, Dubertret C, Le Foll B. Child marriage in the United States and its association with mental health in women. Pediatrics. 2011; 128(3):524-30.

[11] Chaturvedi S., Kapil U., Bhanthi T., Gnanasekaran N., and Pandey R.M., Nutritional status of married adolescent girls in rural Rajasthan. Indian J Pediatr. 1994; 61(6):695-701.

[12] Rudäng R., Mellström D., Clark E., Ohlsson C., and Lorentzon M. Advancing maternal age is associated with lower bone mineral density in young adult male offspring. Osteoporos Int. 2012; 23(2):475-82.

[13] Nour N.M., Health consequences of child marriage in Africa. Emerg Infect Dis. 2006; 12(11):1644-9.

[14] Kuhn L., Denny L., Pollack A., Lorincz A., Richart R., and Wright T., Human papillomavirus DNA testing for cervical cancer screening in low resource settings. J Natl Cancer Inst 2000; 92:818-25.

[15] UNICEF, State of the World's Children, 2009, Retrieved March, 2014 from http://www.unicef.org/sowc09/docs/SOWC09-FullReportEN.pdf

[16] United Nations Population Fund, and United Nations Children's Fund, 2010, Women's \& Children's Rights: Making the connection, UNFPA, New York, p. 39.

[17] Women and Children Legal Research Foundation. Early Marriage in Afghanistan. Deh-Bori: Women and Children Legal Research Foundation; 2008

[18] Hossein Matlabi1, Ahmad Rasouli, Hamidreza Hamedi Behtash, Ali Faraghi Dastjerd, Behnaz Khazemi. Factors Responsible for Early and Forced Marriage in Iran. Science Journal of Public Health. Vol. 1, No. 5, 2013, pp. 227-229. doi: $10.11648 / j . s j p h .20130105 .17$

[19] National Survey on Child Marriage by Plan Bangladesh and icddr,b-2013, Retrieved March, 2014 from http://planinternational.org/where-we-

work/asia/bangladesh/about/publications/national-surveyon-child-marriage-by-plan-bangladesh-and-icddr-b

[20] Bangladesh Literacy Survey, 2010, Retrieved March, 2014 from

http://www.bbs.gov.bd/webtestapplication/userfiles/image/S urvey\%20reports/Bangladesh\%20Literacy\%20Surver\%2020 10f.pdf

[21] Bangladesh Demographic and Health Survey 2007, Retrieved March, 2014 from http://www.unicef.org/bangladesh/BDHS2007_Final.pdf

[22] The Household Income and Expenditure Survey (HIES), 2010, Retrieved March, 2014 from http://www.bbs.gov.bd/webtestapplication/userfiles/image/H IES-10/Cont_Summary(3).pdf

[23] Bangladesh Muslim Marriages and Divorces (Registration) Act-1974 Available http://bdlaws.minlaw.gov.bd/pdf/476__.pdf

[24] Bangladesh Births and Deaths Registration Act in 2004

[25] Bangladesh Demographic and Health Survey 2007, Retrieved March, 2014 from http://dhsprogram.com/pubs/pdf/FR265/FR265.pdf

[26] Sultana N., Chowdhury S.B., Parvin T., Huq S.R., and Ahmed S., (2007). Teenage Pregnancy and Its Outcome in Bangladesh: Has the Situation Improved? 13th Annual Scientific Conference of icddr,b-2007. Abstract number: 109 (006), page- 134

[27] Barakat A., Adolescent reproductive health: A Challenge: South-South Centre, Bangladesh, 2000.

[28] Path/outlook, Adolescent Reproductive Health: Making a Difference; December, 1998, Vol. 16 (3).

[29] Pachuri S., Adolescents in Asia: Issues and Challenges. Demography India 1998, Vol.27. 1. pp. 117-128. 